José Florencio F. Lapeña, Jr. MA , MD

Department of Otolaryngology - Head and Neck Surgery College of Medicine, University of the Philippines Manila

Department of Otorhinolaryngology

Head and Neck Surgery

East Avenue Medical Center, Diliman, Quezon City
Correspondence: Prof. Dr. José Florencio F. Lapeña, Jr. Department of Otolaryngology - Head and Neck Surgery Ward 10, Philippine General Hospital

Taft Avenue, Ermita, Manila 1000

Philippines

Phone: (632) 85548467

Telefax: (632) 85244455

Email: lapenajf@upm.edu.ph,jflapena@up.edu.ph

The author declared that this represents original material that is not being considered for publication or has not been published or accepted for publication elsewhere, in full or in part, in print or electronic media; that the manuscript has been read and approved by the author, that the requirements for authorship have been met by the author, and that the author believes that the manuscript represents honest work.

\section{Death and Dying During the COVID-19 Pandemic: Tahan Na, Humimlay}

\author{
Nagwakas ang araw \\ Lupa't dagat, langit, pumanaw \\ Tahan na, Humimlay \\ Siyanawa \\ — JF Lapeña, Tahan Na, Humimlay'
}

The continuing COVID-19 pandemic has directly or indirectly claimed the lives of countless colleagues, friends, and family. I personally thought my tears had run dry as people I knew and loved died throughout the past year, but the wells of grief run deep, even as the plague continues its scourge as of this writing. Especially when fellow front-liners fall, the haunting bugle call echoes the finality of death: "day is done, gone the sun, from the lake, from the hills, from the sky."1

Of my original fellow office-bearers in the Philippine Association of Medical Journal Editors (PAMJE), two have passed on: Dr. Gerard "Raldy" Goco and Jose Ma. "Joey" Avila. ${ }^{2}$ Even in our Philippine Society of Otolaryngology - Head and Neck Surgery, I do not recall us dedicating so many passages in issues past as we do now, with tributes to Dr. Elvira Colmenar, Dr. Ruben Henson Jr., Dr. Marlon del Rosario, and Dr. Oliverio Segura. Our Philippine Medical Association Central Tagalog Region (PMA-CTR) has lost more than its share of physicians: Dr. Joseph Aniciete, Dr. Patrocinio Dayrit, and Dr. Rhoderick Presas of the Caloocan City Medical Society; Dr. Mar Cruz, Dr. Mayumi Bismarck, and Dr. Edith Zulueta of the Marikina Valley Medical Society; Dr. Kharen AbatSenen of the Valenzuela City Medical Society; Dr. Romy Encanto and Dr. Cosme Naval of the San Juan Medical Society; Dr. Roberto Anastacio and Dr. Encarnacion Cabral of the Makati Medical Society; and Dr. Amy Tenedero and Dr. Neil Orteza of the Pasay Parañaque Medical Society. The rest of the PMA has lost over 145 physicians due to, or during, the pandemic.

As healthcare workers, how do we deal with their deaths, the inevitability of more deaths, and the very real prospect of our own deaths during these trying times? How do we continue our work of saving lives in our overcrowded hospitals and community-based clinics while dealing with grief and facing our own fears for ourselves and our families?

Over 50 years ago, Elisabeth Kübler-Ross formulated a model of dying with five stages of coping with impending loss of life (denial, anger, bargaining, depression and acceptance) 


\section{EDITORIAL}

based on her work with dying patients at the University of Chicago, and these have become widely considered as phases of grief that people go through when faced with the prospect of their own death (or as a response to any major life change). By focusing "on dying, rather than death," her work "shifted attention of religious thinkers, pastors, and authors of personal testimonies onto the themes and framework she offered" and "her legacy was to offer a fresh way to think and speak about dying, death and grieving." ${ }^{4}$ Whether, and how we might appropriate her framework in order to cope with our personal and collective experiences during this pandemic, a pandemic that is arguably worse than any worst case scenario ever imagined, is another matter altogether. Does the framework even apply?

The very nature of the COVID-19 pandemic is changing how people die -- in ambulances, makeshift tents and long queues outside overflowing hospitals, or en route to distant hospitals with vacancies (with patients from the National Capitol Region travelling to as far away as Central and Northern Luzon or Southern Tagalog and Bicol), or in their own homes (as people with "mild" symptoms are encouraged to monitor themselves at home, often rushing in vain to be admitted in hospitals with no vacancies when it is already too late) -- and "we have to make difficult decisions regarding resuscitation, treatment escalation, and place of care,",5 or of death.

The new normal has been for COVID-19 patients to die alone, and rapidly so, within days or even hours, with little time to go through any process of preparation. Friends and family, including spouses, parents, and children, are separated from the afflicted, and even after death, the departed are quickly cremated, depriving their loved ones of the usual rites and rituals of passage. In most cases, wakes and novenas for the dead can only be held virtually, depriving the grieving loved ones of the support and comfort that face-to-face condolences bring. Indeed, the social support systems that helped people cope with death have been "dismantled, and the cultural and religious rituals that help us process grief also stripped away."

Amidst all this, "we must ensure that humanity, community, and compassion at the end of life are sustained," and that "new expressions of humanity help dispel fear and protect the mental health of bereaved families." ${ }^{16}$ What these expressions might be, and whether they can inspire hope in the way that community pantries ${ }^{7}$ have done remains to be seen. But develop these expressions we must, for our sakes as for the sake of our patients. The "hand of God" -- two disposable latex gloves filled with warm water and tied around the hand of a woman with COVID-19 to alleviate her suffering by nurse technician Araújo Cunha at the Vila Prado Emergency Care Unit in São Paulo is one such poignant expression. ${ }^{8}$

Ultimately, we must develop such expressions for and among ourselves as well. As healthcare workers, our fears for ourselves, our colleagues, and our own loved ones "are often in conflict with professional commitments" and "given the risks of complicated grief," we "must put every effort into (our) own preparation for these deaths as well as into (our) own healthy grieving." ${ }^{\prime \prime}$ We cannot give up; our profession has never been as needed as it is now. True, we can only do so much, and so much more is beyond our control. But to this end, let us imagine the soothing, shushing "tahan na" (don't cry) we whisper to hush crying infants, coupled with the calming invitation "humimlay" (lay down; rest; sleep). Yes, the final bugle call may echo the finality of death, but it can simultaneously reassure us that "all is well, safety rest, God is nigh!"1

\footnotetext{
REFERENCES

1. Lapeña JF. Tahan na, Humimlay. 2020. Filipino translation from the lyrics. "Taps." (U.S. Army Bugle Call). @Pennsylvania Military College [Cited 2021 May 12] Available from; https://www. scoutsongs.com/lyrics/taps.html.

2. Lapeña JF. Seasons and Times, Reasons and Rhymes: Di Niyo Ba Naririnig? Philipp J Otolaryngol Head Neck Surg. 2020 Jul-Dec;35(2):4-5. DOI: 10.32412/pjohns.v35i2.1467.

3. Kübler-Ross E. On Death and Dying: What the Dying have to teach Doctors, Nurses, Clergy and their own Families. $1^{\text {st }}$ Edition (40 ${ }^{\text {th }}$ Anniversary Edition) London: Routledge; 2008. DOI: $10.4324 / 9780203889657$

4. Bregman L. Kübler-Ross and the Re-visioning of Death as Loss: Religious Appropriation and Responses. J Pastoral Care Counsel. 2019 Mar;73(1):4-8. DOl: 10.1177/1542305019831943 PubMed PMID: 30895849.

5. Moore KJ, Sampson EL, Kupeli N, Davies N. Supporting families in end-of-life care and bereavement in the COVID-19 era. Int Psychogeriatr. 2020 Oct;32(10):1245-1248. DOI: 10.1017/
} S1041610220000745 PubMed PMID: 32349850; PubMed Central PMCID: PMC7235296.
6. Yardley S, Rolph M. Death and dying during the pandemic. BMJ. 2020 Apr 15;369:m1472. DOI: 10.1136/bmj.m1472 PubMed PMID: 3229575.

7. Mongaya K. Community pantries inspire hope amid pandemic and economic crisis in the Philippines. Global Voices. 5 May 2021. [cited 2021 May 13] Available from: https://globalvoices. org/2021/05/05/community-pantries-inspire-hope-amid-pandemic-and-economic-crisis-inthe-philippines/.

8. From: Técnica em enfermagem de São Carlos 'ampara' mão de paciente intubada com luvas cheias de água morna. G1 Globo. 23 March 2021. [cited 2021 May 13] Available from: https://g1.globo. $\mathrm{com} / \mathrm{sp} / \mathrm{sao}$-carlos-regiao/noticia/2021/03/23/tecnica-em-enfermagem-de-sao-carlosampara-mao-de-paciente-intubada-com-luvas-cheias-de-agua-morna.ghtml.

9. Rabow MW, Huang C-H S, White-Hammond GE, Tucker RO. Witnesses and Victims Both: Healthcare Workers and Grief in the Time of COVID-19. J Pain Symptom Manage. 2021 Feb 6;S0885-3924(21)00164-0. DOI: 10.1016/j.jpainsymman.2021.01.139 PubMed PMID: 33556494 PubMed Central PMCID: PMC7864782. 